\title{
The Anglophone Crisis: The Rise of Arms Trafficking and Smuggling, its Effects on the Two English Regions of Cameroon
}

\author{
Morgan Tebei Nwati \\ Central China Normal University, Wuhan, China \\ Email: brownmorgan732@yahoo.com
}

How to cite this paper: Nwati, M. T. (2021). The Anglophone Crisis: The Rise of Arms Trafficking and Smuggling, its Effects on the Two English Regions of Cameroon. Advances in Applied Sociology, 11, 1-13. https://doi.org/10.4236/aasoci.2021.111001

Received: November 23, 2020

Accepted: January 23, 2021

Published: January 26, 2021

Copyright $\odot 2021$ by author(s) and Scientific Research Publishing Inc. This work is licensed under the Creative Commons Attribution International License (CC BY 4.0).

http://creativecommons.org/licenses/by/4.0/

\section{(c) (i) Open Access}

\begin{abstract}
The union between the English and French-speaking regions of Cameroon has exploded into a violent crisis, questioning the legitimacy of the central government of the country. The main objective of this study is to explore the causes of the Anglophone crisis, to analyze the rise of arms trafficking and its effects on the two English regions of Cameroon. The conflict theory is used as a model of analysis in expatiating the issue of arms trafficking and its effects on the two English regions of Cameroon. This sociological analysis, defines the area of study, bad governance, hardship, and extreme poverty as the main causes of arms trafficking in two English regions. This study also brings to lights: 1) The link between the Anglophone crisis and the rise of arms trafficking and its effects, 2) The rise of arms trafficking and the socio-economic impact of the crisis. The Anglophone crisis, the rise of arms trafficking in the two English regions of Cameroon is a call for concern.
\end{abstract}

\section{Keywords}

Arms, Trafficking, Anglophone, Crisis, Poverty

\section{Introduction and Background}

Cameroon which is in the golf of West and Central Africa has an ethnically diverse population, with more than 250 ethnic tribes or groups. Like most African countries, Cameroon is still covered by the shadow of colonialism. The French and the British took control of Cameroon after the defeat of the Germans in the First World War and Cameroon was divided into two unequal parts. British part of the territory was called Southern Cameroon. Southern Cameroon was a mandated territory of the League of Nation, which implies, Britain was a caretaker 
and to prepare the country for subsequent independence. While France had complete control over her part of the territory which was called the republic of Cameroun. Cameroon shares common borders with Nigeria in the Northwest, Chad in the Northeast Central Africa Republic to the East, Republic of Congo in the Southeast Gabon and Equatorial Guinea to the South, the Atlantic Ocean in the Southwest. Cameroon is surrounded by countries that have been in decades of serious political crisis which escalated into violent political and ethnic conflicts. The term Anglophone crisis constitutes all the various political social and economic problems that the English speaking region of former Southern Cameroon has been facing ever since independence. In 1961, the former British Southern Cameroon (West) Cameroon and the (East) Cameroon the Republic of Cameroon came together in a Union and formed a Federation. The wind of change in Africa during this period was independence. The neighboring (East) Cameroon has gained her independence in 1960. Nigeria had also gained her independence in early in 1961. Besides, the United Nations was putting an end to the trusteeship system. Thus, the British Southern Cameroon was given the choice to choose between joining in a federation with the Republic of Cameroon as two equal states or by joining with Nigeria to be one of its federated states. "The union was in favor of a federation with the Republic of Cameroon". (Konings, 2019); thus a plebiscite was organized between the Republic of Cameroon and British Southern Cameroon in 1961. This plebiscite, brought confusion to most people of Southern Cameroon as they never wanted to join Nigeria nor the republic of Cameroon which spoke French, or which was from a civil war or never wanted to be dominated by the French culture. This was "the beginning of confusion" to many Southern Cameroonians (Konings \& Nyamnjoy, 2003). On April 21st, 1961, United Nations Resolution 1608 (xv) set the 1st of October 1961 as the date of independence for Southern Cameroon, by joining The Republic of Cameroon forming the Federal Republic of Cameroon. French Cameroon and the former British Southern Cameroon met in the town of Foumban to discuss the terms of the Union. At the end of the discussion, the former British Southern Cameroonians went home with a heavy heart saying, the meeting was overpowered by an already drafted constitution from the French experts. This was a turning point in the lives of all the former British Southern Cameroonians, as they are in a marriage with a stranger. The southern Cameroonians came back from the union meeting hoping they will subsequently meet again to hammer out the decisions that will guarantee their union. In August 1961, the Southern Cameroonians met in Yaounde the headquarters of the Republic of Cameroon with the French Cameroons to further cement the constitution. Unfortunately, no decisions were met; thus the plebiscite had no legal backings as no formal Documents were signed between the two Cameroons, giving no basis for the Federation (Achangkeng, 2015). From 1961-1972, the marriage between the two Cameroons was that of inconvenience. Southern Cameroonians on their part were never treated as equals in the union, thus mounting bitterness and hatred in the operating Federal system. Anglophones were not represented enough in 
terms of administrative appointments in both the Federal government and local governing councils; in terms of developmental projects Southern Cameroon was backward. All these grouches have been the main thinking of regrets by many Anglophone Cameroonians.

Furthermore, for the past 50 years, the Anglophones have been treated as second class citizens in a government were marginalization, suppression, cruelty, the abuse of the constitution and the use of force as the main tool in governance by the majority francophone. "In the book betrayal of too trusting a people" (Anyangwe, 2009) explains how the desire for self-determination remains alive in the people of Southern Cameroon even though engaged in their current status. In October 2016, the Cameroon Anglophone Civil Society Consortium and organization made up of teachers and lawyers of the two English regions of the country, NW and SW, took to the streets in a peaceful protest, because the English language which is the language of the Anglophones, have been trampled upon (Aljazeera, 2016). A high number of monolingual French administrators have infested the Anglophone system. French-speaking lawyers were posted into the NW and SW making the French language the language used in courts in court proceedings. Most administrative documents were all in French creating a complete francophone Union. Also, Francophone teachers were posted into the Anglophone region. Most of these teachers could not speak English nor could the students understand French, creating a non-learning atmosphere. The teachers and lawyers were rough-handled on the Streets my members of the government military. Taxi drivers, local moto-taxi commonly called "Okada", university students all turn out against the government. The streets of Bamenda and Limbe were full of demonstrators. President Paul Biya gave orders, for the military to use live ammunition to the demonstrators. "The crisis in Cameroon's English speaking region has turned violent" (Quartz, 20117). The lawyers called on the government to redress the situation of the lawyers and teacher, in the two English regions of Cameroon. As things continue to fall apart, and as the military continues to use force to calm down the tension, southern Cameroonians under the leadership of Sisiku Ayuk Tabe, with the already formed interim government. On the 1st of October 2017, Ayuk Tabe and the team declared the independence of Ambazonia. Even though on Exile Sisiku Tabe had a large army the Ambazonia Defense Force (ADF) with manpower of over 1500 militia. On the 30th of December, the president of the Republic Paul Biya declared war on the Anglophone separatist. This was the beginning of the Anglophone war. The war started in Manyu which is the ADF based, and like wildfire, it has taken over counties like lebielem, Fako, Momo Bui, and Nkoketungia. Also, several arm groups have emerged, such as the Red Dragon, Tigers, ARA, and seven Kata, amongst others. Hundreds of homes and property have been destroyed in villages like Kwa-Kwa, Nso, Tadu, Kembong, and Muyenge. On the 5th of January 2018 members of the Ambazonia interim government, including President Sisiku Ayuk Tabe were all abducted from Nigeria and brought to Cameroon. They were subsequently arrested and they spent more than 10 months in the gendar- 
merie. Sisiku Ayuk and the team were later sent to the maximum-security prison in Yaounde pending trial. The trial started in December of 2018 (Watch, 2019). On the 4th of February 2018, it was announced that Dr. Samuel Ikume Sako will be the new interim president of the Republic of Ambazonia, taking over from Ayuk Tabe because he is jail. There was tension amongst the leaders of Ambazonia. On the 2nd of May 2019, Sisiku Ayuk dissolved the interim government of Dr. Ikume Sako and reinstate his cabinet, thus causing a divide amongst the leadership. On the 13th of May 2019, the United Nations Security Council had an informal meeting talking about the Anglophone crisis. The Anglophones were so happy that finally their issue has been heard by a higher authority. "United Nations security council to discuss Cameroon's escalating crisis” (Kindzeka, 2019). On the 26th of August, 2019 an appeal was put forth by the Ambazonian leaders, including Sisiku Ayuk to put an end to their Sentence After being convicted in a military court. Sisiku Ayuk and team were later sentenced to life in prison on the charges of Terrorism, secession and with a fine 350 million dollars

The above narrative paints a picture of the status of the two English regions of Cameroon, a country which has been in crisis that started with a peaceful protest in 2016 between teachers and lawyers. Today this peaceful demonstration has grown into a fierce battle where the military is being faced by almost equal strength with the secessionist. For decades, Cameroon has been surrounded by neighboring countries suffering from, tribal conflicts to civil war and even terrorist invasion like in the case with Nigeria. The huge boarders of Cameroon have always been a weakness to the country in terms of border management. This is because of insufficient man power to control the vast borderline; Cameroon has with its neighbors. Thus the "free movement of people has allow the movement of guns and illegal ammunitions" (Thukur, 2011) through the weak borders the country has. For example, in the case of the Central Africa Republic, they had a civil war from 2005-2014 where then rebels agreed on a cease-fire, thus keeping an alive trade of arms trafficking and smuggling. Also, in the case, of Nigeria, "the rise of Boko Haram in Nigeria" (Cook, 2020), explains that, Boko Haram sprung up in 2002 as a nonviolent Islamic movement in Northern Nigeria. But as of 2015, Boko haram has been named the deadliest Islamic group in the world. Also, Chad or the Republic of Chad had a crisis in 1978-1990, further, enhancing the recycling of weapons from one crisis to another. In this case, Cameroon was a ready market for arms trafficking and smuggling. In addition, with the rise of the Anglophone crisis, a crisis that progressively turned form nonviolent to deadly conflict serves the purpose of this illegal trade. A trade which was inspired by Anglophone Cameroonians looking for a means to defend their families and property as they will say. The heavy handed manner in which the government handled the 2016 peaceful protest ignited the flames of the crisis.

\subsection{Theoretical Analysis Model and Methodology}

\subsubsection{Theoretical Analysis Model}

Several theories have been used to analyze the issue of conflict and tension 
within communities. In understanding this phenomenon, the conflict theory by Karl Marx is suitable especially in our situation. Karl Marx's theory of conflict focuses on a variety of assumptions that explain why tension and coercion occur in our society. Marx further postulates that society is always in constant conflict because of competition for limited resources. Thus there is a class conflict between the bourgeoisie (the owners of the means of production and capital), and the proletariat (the working class). Marx further affirms that Ideological coercion by the bourgeoisie is a source of conflict. The bourgeoisie will trick the poor to accept conditions that will not favor them in the long run and this will lead to conflict. In the case of Cameroon, those in control of power, both political, socio-economic power are the majority which is the French-speaking part of the country. The French-speaking people of Cameroon tricked the English minority to enter into a union which they will eventually be the superpower in the so call equality union which they had 1961 (Plebiscite). From plebiscite (1961) to date, the English speaking Cameroonians are living a life full of regret, wishing never to have joint the Republic of Cameroon to form a Federal government. The 2016 protest by the teachers and lawyers, was just one of the manifestations. The government thought relying on the military (use of force) to quell the pressure is the best idea. This was just the beginning of the "Ambazonia war" as many local people will say.

Furthermore, in understanding the rise of arms trafficking and its effects, the Conflict theory brings out possible reasons for the rise of the crisis and also an assumption on how the crisis might end. Marx's theory emphasizes the power of ideology. In Cameroon today, the English speaking Cameroonians, are tired of the cultural hegemony and suppression they had faced for the past 50 years from the ruling majority. The Anglophones want to reinstall their identity, their language, and even their laws which are the common law.

According to (Wright, 2000), the rise of the power elite brings a different face on the understanding of our contemporary society. Mills further explains that this power elite will rise in terms of military, economic and political figures. In Cameroon per se, the Anglophones already have a standing group of armed secessionist, they receive financial support from the diaspora, and already have their leader, thus the rise of a "tiny power elite" (Wright, 2000).

Marx also affirms that as the wealth gap increases tension and conflict increase. The outcome of this rising tensions according to Karl Marx is a revolution, which is what is happening in Cameroon today.

Furthermore, the social Capital theory also gives a better understanding of the phenomenon of arms trafficking and its effects on the two English regions in Cameroon. Pierre Bourdieu uses social capital to paint the reality of social inequality within communities (Bourdiue, 1930).

Social capital reflects on "it is not what you know but who you know". Perfectly in the case of Cameroon, only those in the position of power benefit from the system. Thus social capital examines how social relationships once formed can benefit individuals and organizations beyond their original context of crea- 
tion. Unfortunately, Cameroon is trapped in the web of the arms trade especially with the ongoing arms conflict in the English region of the country. According to (Humaniterian, 2014), "Arms smuggling to Boko Haram threatens Cameroon". Cameroon has always been in the triangle of arms trafficking in the North of Cameroon, trafficking arms from Sudan, Chad, Central Africa Republic, and Nigeria. With the current crisis in the English part of Cameroon is just an extension of the trade. The effect of the arms trade on the English region of Cameroon, is stepping from one the trading environment to another area. The social capital theory is an extension for a better understanding of how individuals and organizations can profit from the present arms trafficking in Cameroon. Thus the shift of arms trafficking to the English region in Cameroon is as a consequence of the already exiting, beneficial arms market in Cameroon.

\subsubsection{Methodology}

The choice of two English regions of Cameroon as our case study shows how relevant arms trafficking and smuggling can be a major call for concern. Cameroon which is in the golf of Central Africa, used to be one of the most peaceful countries in the African continent. With the rise of globalization and advancement in technology, couple with the porous nature of the borders of not only Cameroon but most African countries, Makes it easier for the free movement of people and illegal military annunciations across borders. Furthermore, the issues of arms trafficking and smuggling in Cameroon is a bottom to top issues, as not only arms are being imported but also made in the country. Local communities also rely on the income from the weapons manufacturing for their day to day survival.

Concerning the methodological perspective, this article is exclusively base on an explanatory approach with qualitative characteristics. Qualitative information was acquired through the analysis of documents, such as articles magazines, books newspapers, reports and speeches amongst others. Scientific sites were also used in the gathering of secondary and primary data in the analysis of the wonder arms trafficking and its effect on the English peaking people of Cameroon. The data analyzed in this study give an understanding of the relationship between the rises of arms trafficking and the Anglophone crisis in the English regions of Cameroon.

\section{The Causes of the Rise of Arms Trafficking and Its Effects on the Two English Regions in Cameroon}

Cameroon our case study, lies in the golf of central and west Africa sharing a huge borderline with countries like Nigeria in the Northwest, Chad in the North East, the Central Africa Republic to the East, Republic of Congo in the Southeast Gabon and Equatorial Guinea to the South and the Atlantic Ocean in the Southwest. All these exiting borders are trade routes that have existed since the history of time. In recent times, this huge border has been a "curse rather than a blessing" to the government of Cameroon. In 2002 the Boko Haram's Islamiza- 
tion started and in Northern Nigeria. By 2012-2014, Boko Haram started recruiting soldiers from the Far Northern regions of Cameroons and Chad. Arms trafficking and smuggling like any illicit trade, is a very lucrative trade in which individuals and organizations involved in the trade and profit hugely from it. With the extensive border of Cameroon with Nigeria, Chad, and Central Africa, it opens the Country for any illicit trafficking which arms are one. According to (Heungoup, 2016) "Boko Haram in Cameroon" explains that in the far Northern region of Cameroon, Kousseri which is a border town serves as a center for logistics for Boko Haram. This transit town enables a safe passage of the weapons into Nigeria. Fotolo another small town also serves the same purpose as a transit point into Nigeria. Unfortunately for Cameroon, 2016 was a breakthrough for this trade to be made possible in the Two English regions of the country. The Anglophone crisis as the media calls it, started as a peaceful demonstration by teachers and lawyers to a mature arm conflict. From 2016 till the present date, there has been serious arms conflict in the two English regions of the country. The other eight remaining regions have been peaceful to some extent. During this period of conflict, there has been an evolution in the types of arms used by the separatist fighters, from locally made guns and Machete to automatic powerful weapons like machine guns. Pictures on social media show the separatist have almost the same strength as the Cameroon military.

Demographic factors are also a very important factor, favoring the rise of arms trafficking and its effects on the two English regions of Cameroon. Before the crisis, the English speaking community in Cameroon is recognized by many as the abandoned state. Like many African countries, Cameroon has a youthful population implying lots of available "manpower to do work". Upon graduation from the University or any higher institute of learning, above $80 \%$ of the population of the youths, go without jobs. Thus Cameroon is suffering from underemployment, most of the youths will end up in the most common "Okada" the moto-taxi riders. According to (Alexander Lamarche, 2019), "since independence from 1960, the North West and South West have also been in social political tension, driven largely by grievances of marginalization of the Anglophone people" For the past 60 years, this situation has been worsening in the Anglophone community. This is because the government of Cameroon is based on "man know man" which implies if you don't have a family in the government you are nobody. Most of the youths in Two English regions have faced these challenges, were in job opportunities which they truly think they deserve were given to the French-speaking people. Anglophones youths have been neglected by the government of Cameroon. Resistance too many is the only way to bring equality into society. Most of the Anglophones youths, unfortunately, are part of the arms trafficking organizations. With the extensive border with Nigeria, most of the youths, bypass border control using earth-ways to carry on the trade, the trade is lucrative and they believe it's for the better good for the country.

The Cameroon military has a huge role to play concerning the rise of arms trafficking in the two English regions of the country. This is because as the main 
security body in the country, they have the obligation to stop the illegal manufacturing and sales of arms and ammunition in and out of the country, thus stopping the trade. But on the other hand, the huge border is a problem. (Rackley, 2017), explains that "Cameroon far north responding to Boko Haram" has been an exposure of the weak and incompetent nature of the Cameroon military. Even though the military is doing the best, or whatever they can do to fight this new phenomenon especially in the two English regions. There is shortage of military personnel to control the extensive borders Cameroon shares with its neighbors, thus making military patrol across the border almost impossible for the Cameroon military. On the southwestern border of Cameroon and Nigeria is the Atlantic Ocean, making it very impossible to control of the overall territory.

Furthermore, the socio-economic situation of the two English regions of the country is also a very important factor to encourage the rise of arms trafficking in the two English regions of the country. The situation of the two English regions of Cameroon and Cameroon, in general, is characterized by extreme poverty, illiteracy, and very low school enrollment. Also local arms producers in Cameroon especially in the Northwest and southwest region also really on the manufacturing of these arms for their day to livelihood, thus proving a local source of the supply of weapon to fuel the crisis According journal du Cameroon "The governor of the restive North West region of Cameroon warned those involved in the manufacturing and sale of illegal weapon to desist from such act" (Joiurnal du Cameroun, 2020). In addition, without break of these crisis most of the local arms dealers had boom in the sales of their products as the local population needed arms to defend their rights and freedom as the people will say.

\subsection{The Link between the Anglophone Crisis and the Rise of Rising of Arms Trafficking and Its Effects on the Two English Speaking People}

Since the beginning of the Anglophone crisis in 2016, there has been civil unrest in the two English regions of the country. A crisis that started with a peaceful protest, has grown into a mature arm conflict over the years, also with the high-handed manner in which the government of Cameroon handled the crisis by sending well-armed soldiers, both on land and helicopter gunships, shooting live bullets to the protesting civilians. According to (ACLED, 2018), "Picking a fight, the rise arm separatist in Cameroon" explains that, English speaking Cameroonians are manning up resources to pick a fight with the government. Also by this time, more than 40 Anglophones have already been killed by the government, including untold numbers of the arrest. The English speaking region is under martial law. Many families are saying their sons are being targeted, as youths above the age of 20 started disappearing, while some found lifeless on the streets. As many will say "enough is enough" the Anglophones under the leadership Sisiku Ayuk Tabe formed the Ambazonian Defense Force (ADF), to protect the Anglophones from the killings of the Cameroon military. The ADF militia started with more than 1500 followers with 20 bases spread across the 
Anglophone territory. Most of them armed with cutlasses, spears, and locally made guns. With this rising tension, on the 1 of October 2017, the Ambazonians leaders declare the independent Republic of Ambazonia. There was a mass demonstration across the two English region people celebrating their independence. This was followed by massive military demonstrations against the new state. On the 4th of December 2017, the Cameroon government declared war against the Anglophone movement. With the declaration of war, implies the use of full military force against the Anglophone movement. Also with the already existing arms market in the North of Cameroon, individuals and organization took as an opportunity to explore the already existing arms trade in the North of Cameroon.

The issue of arms trafficking is a global problem. Arms conflicts are scattered in every continent of the world making the issue an emergency crisis. Arms trafficking in Africa and Cameroon in particular, is a call for concern. According to (International, 2017), "Twelve Billion bullets are produced every year" this means the bullets are enough to kill almost everyone in the world. The illegal sales of arms to African countries have course untold sufferings to millions of Africans including Cameroon in Particular. Thousands of deaths, thousands of displaced persons, gender-based abuses, and hundreds of villages burned, according to (Adeniyi, 2017) "The human cost of uncontrolled arms in Africa" is alarming. Unfortunately, today in Cameroon, the crisis is not only the Anglophone crisis but a crisis characterized by hatred and payback. Most people are using the crisis to commit terrible atrocities. Others paying gangs to eliminate their enemies, families paying gangs to collect their old debts amongst others. Local arms manufacturers and local gun dealers who sell imported guns and ammunition, are exploiting the situation to expand their trade. Cameroon is decaying internally and it is a call for concern.

\subsection{The Socio-Economic Effect of the Anglophone Crisis on the Two English Speaking People and Cameroon in General}

While Africa is witnessing rising political tensions, deadly civil wars, the world watches hopelessly. International organizations such as the United Nations and the African Union hold back to the positions of "paper Tigers" while things fall apart for those African countries. The Middle East and Africa are leading the scale of conflict and terrorism in the world. After South Sudan, Mali, Niger, Gabon, Nigeria, Cameroon follows with one of the fastest-growing political crises in the world according to the United Nations. According to (Thimothy Bestly, 2014) in the study of the "legacy of historical conflict: Evident Africa" shows that most violent conflicts are usually in weak and poor country characterized by bad governance. In the case of Cameroon, it has been more than 50 years of the Anglophones living on a day to day complaining about the situation of bad governance, "Deaf Ears" is all that most leaders have in many countries especially in developing countries like Cameroon. In African and Cameroon in particular, the forces of repression have aggravated social conflicts to acute political conflicts 
just like in the case of Sudan and now the two English regions of Cameroon.

Cameroon had only one serious political instability which was widely faced in 1990. Which was widely called the Ghost town, with the Social Democratic Front (S.D.F), seeking for political reforms and in some cases there were clashes with the central government. Most of these conflicts are characterized by, forceful displacement of thousands, loss of property sexual abuses and economic stagnation. Most countries that have had conflicts confirm that the best way to solve a political conflict is not by war. Unfortunately for Cameroon, a crisis that started with a peaceful protest by the Lawyer's and teacher's trade union ended in a mature arms conflict. The conflict in Cameroon has breakdown the Social Structure and unity that had existed for more than 50 years. Both the English and the French peaking people have been coexisting even in a tough climate, but in one void from violence.

Businesses in the two English regions have been paralyzed by the constant ghost town organized by the separatist. These Ghost towns have blocked inter-city businesses, while local village markets which serves as the main source of food supply to the cities, has been shut down. Thousands of people are jobless because of the crisis. According to the general manager of the second-largest employing body in Cameroon the, Cameroon Development Cooperation (CDC) in a Cameroon radio-television program, he explains that more than 7000 direct jobs in the rubber sector, 5000 in the banana sector and 4500 in the palm sector have been ineffective as the crisis hits the Southwest region. The production of goods and services has dropped to $75 \%$ as most of the sectors in the CDC are not effective. Also the Upper Noun Valley Development Association (UNVDA) one of the powerhouses of rice production in Cameroon had witnessed a massive drop in output from 200 tones to less than 5 tons of rice production in the harvest period.

In the domain of Education, the separatist has used the educational sector as a bargaining chip according to (Krippahl, 2019). Teachers and even students have been kidnapped, according to (Tah, 2019), "schools have been shut down" some burnt down to ashes. Parents are unable to send their children to schools because of insecurity. Besides, with the constant Ghost towns, both private and public schools are unable to operate, thus leading to a huge number of school dropouts. There is more than $80 \%$ of school dropouts in the two English regions of the country, with families moving to other regions of the country where their children can go to school. Parents prefer their children to stay at home for the risk of being short as analyzed, according to the (Guardian, 2019). Also, there is an increase in the level of crime rate with a $45 \%$ increase, a high percentage of school dropout will mean a high degree of crime. Alcohol and drug abuse have also been on the rise with a $70 \%$ increase among children of school age according to the inspector general of the Bamenda II police.

Furthermore, the social system in the two English regions is broken. Water supply and electricity are constantly in shortage. It is common for people in the two English regions not to have electricity supply for more than a month. The 
local government has weaponized the electricity. According to the local people, the government is using electricity as a mean to control the crisis. In longer periods of no electricity this mean the conflict in that area is so serious, thus rationing the supply of electricity in terms of areas of peace and stability. The condition of Health centers is deteriorating. Most Rural areas have not been able to have health personnel from 2016 till date. Due to the constant ghost town roadblocks and travel restriction has made it impossible for the sick and needy to have health care.

We cannot forget about the culture of the people, traditional norms have been broken as the traditional rulers were kidnapped and requested for Ransom. The rural areas were the most affected by the crisis since the separatist were operating from villages. For example, the ADF started in Manyu division, thus terrorizing the entire southwest region, as they have constant combat with the military over territory.

Also, the crisis exposes the wrong side of social media in Cameroon. The separatist used social media to inflict fear and terror amongst the local population. With the constant ghost town and the travel ban, most people were caught in the web of fear. More than 500 thousand people have been internal and externally displaced due to the crisis. Villages are left with a very scanty population as most the youths are crowded in neighboring nonviolent regions while 70 thousand refugees are in next-door Nigeria, seeking for safety. With such manipulation with the use of social media, the government decided to barn internet connection for 91 days in the two regions.

\section{Conclusion}

The English speaking people of Cameroon have witnessed devastating consequences because of the rise of arms trafficking in the country. Due to the poor handling of the crisis by the use of the military, the ADF sprung up. With the rise of these defense forces, individuals and organizations, involved in arms, equipment and logistics trade, have made the English speaking Cameroon a market for their resources.

The relationship between the Anglophone crisis and the rise of the arms trade has a positive relationship. It is also important to note that, the rise of the arms trade in Cameroon has led to grievous socio-economic effects on the English speaking region and Cameroon in general.

Besides, this article also pinpoints the role played by the international community such as the United Nations and the African Union in the fight against arms trafficking not only in Cameroon but in the whole sub-Sahara Africa as being weak. Many claim that international organizations are playing the role of a "paper tiger". Their emergency response to a crisis is too slow and even weak, thus creating a continuous circle of the crisis.

In the end, the rise of arms trafficking in the two English regions of Cameroon is a disease and can be cured.

The government of Cameroon should first acknowledge there is an Anglo- 
phone crisis, and then dialogue can bring peace.

The government should stop all sorts of ghost town to encourage accessibility and normalcy of life.

Also, the government should call the so-call separatist for an immediate cease-fire on both sides to bring peace and calm.

All neighboring countries having the same arms trade situation should work with each other to manage their border crisis, and this can be done by having well-trained border police officers.

The international community should step up with its emergency program, in other to respond timely to international situations when needed.

\section{Conflicts of Interest}

The author declares no conflicts of interest regarding the publication of this paper.

\section{References}

Achangkeng, F. (2015). Founban Constitutional Talks and Prio Intentions of Negociating. Journal of Global Initiatives, 9, 146-147.

Acled (2018). Picking a Fight: The Rise of Armed Separatists in Cameroon. https://acleddata.com/2018/09/21/picking-a-fight-the-rise-of-armed-separatists-in-cam eroon/

Adeniyi, A. (2017). Human Cost of Unconyrolled Arms in Africa. https://www-cdn.oxfam.org/s3fs-public/file_attachments/rr-human-cost-uncontrolledarms-africa-080317-en.pdf

Alexander Lamarche, A. F. (2019). Crisis Denied in Cameroon: Government Refusal to Recognize Suffering in NWSW Deters Donors. Washington DC: Refugee international.

Al Jazeera. (2016). Cameroon Teachers, Lawyers Strike in the Battle for English. Aljazeera, 1-5.

Anyangwe, C. (2009). Betrayal of Too Trusting a People. Bamenda: Langaa PRCIG.

Bourdiue, P. (1930). The Forms of Capital. In J. Richardson (Ed.), Handbook of Theory and Research for the Sociology of Education (pp. 241-258). Westport, CT: Greenwood. http://www.socialcapitalgateway.org/content/paper/bourdieu-p-1986-forms-capital-ric hardson-j-handbook-theory-and-research-sociology-educ

Cook, D. (2020). The Rise of Boko Haram in Nigeria. https://ctc.usma.edu/the-rise-of-boko-haram-in-nigeria/

Guardian, T. (2019). Stay Home or Risk Being Shot: Cameroon's Back-to-School Crisis. https://www.theguardian.com

Heungoup, H. D. (2016). Q\&A: Boko Haram in Cameroon. https://www.crisisgroup.org/africa/central-africa/cameroon/q-boko-haram-cameroon

Humaniterian, T. N. (2014). Arms Smuggling to Boko Haram Threatens Cameroon. https://www.thenewhumanitarian.org/news/2014/02/21/

International, A. (2017). Arms Control. https://www.amnesty.org/en/what-we-do/arms-control//arms-control/

Joiurnal du Cameroun (2020). Anglophone Crisis Dragging on Due to Manufacturing and Sales of Arms in NW. Joiurnal du Cameroun, 1-5. https://www.journalducameroun.com/en/cameroon-anglophone-crisis-dragging-on-d 
ue-to-illegal-manufacturing-sale-of-arms-nw-governor/

Kindzeka, M. E. (2019). UN Security Council to Discuss Cameroon's Escalating Crisis. https://www.voanews.com/africa/un-security-council-discuss-cameroons-escalating-cri sis

Konings, P., \& Nyamnjoy, F. (2019). Anglophone Secessionist Movments in Cameroon: Aspiration, Grievence, Performance, Disenchantment. In L. de Vries, P. Englebert, \& M. Schomerus (Eds.), Secessionism in African Politics (pp. 59-89). Cham: Palgrave Macmillan. https://doi.org/10.1007/978-3-319-90206-7_3

Konings, P., \& Nyamnjoy, F. (2003). Negotiating an Anglophone Identity. Afrika-Stdiecentrum Series, 1, 8-11.

Krippahl, C. (2019). Cameroon: Anglophone Separatists 'Use Children as a Bargaining Chip'.

http://cameroon.mynews.club/news/cameroon-anglophone-separatists-use-children-as -a-bargaining-chip.html

Wright, M. C. (2000). Power Elite. Oxford: Oxford University Press.

Quartz. (20117). The Crisis in Cameroon's English-Speaking Regions Has Turned Voilent with Boombings.

https:/qz.com/africa/1084943/cameroons-anglophone-crisis-turns-violent-as-presiden t-paul-biya-speak-at-unga-2017/

Rackley, E. B. (2017). Cameroon's Far North: Responding to Boko Haram.

https://reliefweb.int/report/cameroon/cameroon-s-far-north-responding-boko-haram

Tah, P. (2019). Cameroon Conflict Keeps Schools Shut.

https://www.bbc.com/news/world-africa-49529774

Timothy, B., \& Marta, R.-Q. (2014). The Legacy of Historical Conflict: Evidence from Africa. American Political Science Review, 108, 319-336.

Thukur, H. A. (2011). The Dark Side of Globalisation. Tokyo: United Nation University Press, 72-74.

Watch, H. R. (2019). Cameroon: Separatist Leaders Appeal Conviction.

https://www.hrw.org/news/2019/09/03/cameroon-separatist-leaders-appeal-conviction 